\title{
The Effect of Teacher Motivation and Success on SD Negeri 01 Simpang Agung, Simpang Sub-District Learning Outcomes
}

\author{
Mutasor $^{1 *}$, Yasir Arafat ${ }^{2}$, Alhadi Yan Putra ${ }^{2}$ \\ ${ }^{\text {l} S D ~ N e g e r i ~} 01$ Simpang Agung, South of Sumatera, Indonesia \\ ${ }^{2}$ Universitas PGRI Palembang, Indonesia \\ *Corresponding author. Email: mutasor54@gmail.com
}

\begin{abstract}
This study is inspired by the need for improvement in teacher motivation and success. The aim of this study is to evaluate the impact of teacher motivation and success on student learning outcomes at SD Negeri 01 Simpang Agung, Simpang Sub-District, South OKU Regency. The research approach is quantitative, with a population of 249 people and a survey of 153 respondents, and data collection strategies using questionnaires and documentation of learning outcomes. students, then tested using the SPSS version 2.5 program. Hypothesis testing at the 5\% significance level with t-test. In conclusion, $\mathrm{H}_{1}$ is accepted, this shows that there is an effect of $43.1 \%$. To be declared accepted, this indicates that there is an effect of $26.4 \%$. To test the effect simultaneously, the F-test is used, which results in acceptable $\mathrm{H}_{3}$, with a large effect of $52 \%$. The implication of this research is used as input for the principal, because the supervision of the principal is highly expected by the teachers, because the principal is the person who plays a role in fixing teacher motivation and performance to be better.
\end{abstract}

Keywords: Motivation, Teacher, Performance, SPSS

\section{INTRODUCTION}

Education is a deliberate and organized attempt to establish a learning environment and learning process in which students actively cultivate their capacity for religious spiritual power, self-control, intellect, personality, and noble character. Education plays a critical role in enhancing the quality of human capital and achieving the values of the Indonesian people in terms of general welfare and educating the nation's life. The achievement of educational goals is very much determined by the various elements that support it, students as educational subjects can be directed to formal and informal education. Formal education is a formal and tiered educational route that includes basic education, secondary education, and higher education. Meanwhile, informal education is a type of education that exists outside of formal education. In the sense that it is not conducted in a formal and tiered manner, such as research tutorials, classes, and so on.

The effect of teacher motivation on student learning outcomes in Madrasah Aliyah economics subjects, the goal of national education is to help students realize their full potential as human beings who believe in God Almighty, have noble character, are safe, intelligent, competent, imaginative, and self-sufficient, and become democratic and responsible citizens. As a result, the structure of the educational system must be tailored to the trends and needs of development. Education may also be described as a learning process that helps individuals to gain a better understanding and knowledge of specific objects and specifications [1].

From the above opinion it can be concluded that motivation is carried out in order to provide encouragement or enthusiasm for students so that they can be even more active and more serious in learning so that they can get better results which can create a good achievement.as well as being able to make the students as quality human resources.

Welfare greatly affects teacher performance. Because the welfare is often stagnant and the numbers are not large, the teaching function of teachers is no longer unanimous, holistic and comprehensive. Furthermore, teacher must be sincere and serious in educating students. Even so, teachers are also humans who need money to eat, drink, etc. [2].

Motivation is an impulse that exists in a person either because of his own awareness or because of an external urge to do something in the hope that the desired goal can be achieved. The good level of performance of a teacher as an educator in schools is the 
reason for this research, as part of contributing to improving the quality of education [3].

Behavior and can be seen as a change in energy in a person which is marked by the appearance of feelings and is preceded by a response to a goal. This statement holds three meanings, namely: (1) motivation is the beginning of an energy change in each individual; (2) motivation is characterized by a person's feeling, affection, and (3) motivation is stimulated because of a goal [4].

Teacher results, with an emphasis on meaningful learning for students [2]. Permendiknas number 41 of 2007, that learning must meet process standards including planning the learning process, implementing the learning process, assessing learning outcomes for the implementation of an effective and efficient learning process. Teacher performance is the work achieved by the teacher in learning. The factors that affect teacher performance include: (1) personal or individual factors;c(2) leadership factors; (3) team factors, and (4) system factors [5].

According to Hilgard [6], learning results are abilities acquired by individuals during the learning process, which may result in improvements in actions, awareness, comprehension, attitudes, and skills of students, causing them to be better than before.

Learning outcomes can be described as the best results a student has obtained after going through the teaching and learning process in order to learn a specific subject. Learning results are not only in the form of principles, but may also be in the form of constructive improvements, reasoning, discipline, skills, and so on [7].

Learning outcomes are seen in the form of individual skills and ability to act. There are six skill levels, namely: reflex movements (skills in unconscious movements), skills in conscious movements, perceptual abilities, including distinguishing visuals, distinguishing auditive, motoric and others, abilities in the physical field, such as strength, harmony and consistency, skill movements, from simple skills to complex skills, abilities relating to non-recursive communication, such as expressive and interpretive movements [8].

This study was based on the findings of Lian and Fitria [3], who discovered that work motivation has a positive and important impact on success. This is, of course, assuming that the other variables are stable or constant and that the test is performed partially or independently.
The research that has been described is research that is similar to the research that the researcher will do. The study revealed variables that were almost the same as this study, namely those related to teacher motivation, performance and results of learning outcomes. However, the studies that have been described have several differences with this research, including in the place of research, time of research, research scope and instruments used at the educational institution level.

Based on observations at SD Negeri 01 Simpang Agung, Simpang Sub-District, students' attitudes about how to teach teachers and the use of learning aids are still not good enough so that it can affect student learning motivation.

\section{METHODS}

This quantitative research approach may also be defined as a research method centered on the positivist theory, used to perform research on particular populations or samples, data collection utilizing research instruments, quantitative/statistical data analysis, with the aim of testing predetermined hypotheses.

The result stage of data processing will be interpreted in the form of analysis to build a conclusion in response to the research objectives. This study will be checked using the SPSS software to determine whether the research hypothesis is approved or rejected.

The hypotheses of this research are: (1) $\mathrm{H}_{1}$ is accepted if there is an effect of teacher motivation on student learning outcomes in South OKU Regency; (2) $\mathrm{H}_{2}$ is accepted if there is an effect of Teacher Performance on student learning outcomes in South OKU Regency, and (3) $\mathrm{H}_{3}$ is accepted if there is an influence of teacher motivation and teacher performance on student learning outcomes in SD Negeri 01 Simpang Agung, Simpang Sub-District.

\section{RESULTS AND DISCUSSION}

\section{1) Description of teacher motivation data}

Motivation variables were calculated using a survey with a 5-point likert consisting of 21 statement items at SD Negeri 01 Simpang Agung, Simpang Sub-District, South OKU Regency, South Sumatra Province. Scores for tutoring ranged from 21 to 105 .

Table 1. Description of teacher motivation data

\begin{tabular}{lcccc}
\hline No & Interval & Frequency & Percentage & Category \\
\hline 1. & $96-100$ & 16 & $35.55 \%$ & Very Agree \\
\hline 2. & $87-95$ & 14 & $31.11 \%$ & Agree \\
\hline 3. & $78-86$ & 10 & $22.22 \%$ & Middle \\
\hline 4. & $69-77$ & 2 & $4.43 \%$ & Not agree \\
\hline 5. & $61-68$ & 3 & $6.67 \%$ & Very not
\end{tabular}




\section{2) Description of teacher performance data}

Teacher output variables were calculated using a survey with a 5-point likert consisting of 23 statement items at SD Negeri 01 Simpang Agung, Simpang SubDistrict, South OKU Regency, South Sumatra Province. The tutoring score varies from 23 to 115 .

Table 2. Description of teacher performance data

\begin{tabular}{ccccc}
\hline No & Interval class & Frequency & Percentage & Category \\
\hline 1. & $104-112$ & 15 & $42,22 \%$ & Very Agree \\
\hline 2. & $96-103$ & 14 & $31.11 \%$ & Agree \\
\hline 3. & $88-95$ & 7 & $15.56 \%$ & Middle \\
\hline 4. & $81-87$ & 4 & $8.89 \%$ & Not agree \\
\hline 5. & $74-80$ & 5 & $11.11 \%$ & Very not \\
\hline
\end{tabular}

\section{3) Description of learning outcome}

Learning outcome variables in research at SD Negeri 01 Simpang Agung, Simpang Sub-District, South OKU Regency, South Sumatra Province were measured using documentation of grades VI.A, VI.B, VI.C. The learning outcomes of these students are conditioned on the learning outcomes of the odd semester of the 2020/2021 school year. The number of students is 108 people.

\begin{tabular}{ccccc}
\hline \multicolumn{5}{c}{ Table 3. description of student learning outcomes } \\
\hline No. & Interval class & Frequency & Percentage & Category \\
\hline 1. & $680-584$ & 8 & $7.4 \%$ & Verygood \\
\hline 2. & $574-579$ & 51 & $47.22 \%$ & good \\
\hline 3. & $568-573$ & 22 & $20.37 \%$ & middle \\
\hline 4. & $563-567$ & 24 & $22.22 \%$ & bad \\
\hline 5. & $558-562$ & 3 & $2.78 \%$ & Very bad \\
\hline
\end{tabular}

\section{4) Test the normality of variable $X 1$ against variable} Y

By paying careful attention to the normality test criteria. If the significance value is greater than 0.05 , the data is usually distributed, and the results of the SPSS processing One-Sample Kolmogorov-Smirnov Test on the normality test indicate that the value Asymp. (2tailed) 0.118 is greater than 0.05 . It is possible to assume that motivation data and effective teaching data are said to be normally distributed.

\section{5) Test for normality of variable $X 2$ with variable $Y$}

The results of the One-Sample KolmogorovSmirnov Test on the normality test show that the Asymp.Sig.(2-tailed) $0.069>0.05$ by paying attention to the normality test criteria above, namely if the significance value> 0.05 then the data is normally distributed. It can be inferred that the data on learning enthusiasm and learning results are said to be normally distributed.

\section{6) Linearity test of variable $X 1$ to variable $Y$}

Paying attention to the criteria of the linearity test in the Anova Table indicates that the value of Deviation from Linearity is $0.653>0.05$, indicating that teacher motivation variables have a linear relationship with the learning outcome variable.

\section{7) Linearity test of variable $X 2$ with variable $Y$}

There is a linear relationship between the independent variable and the dependent variable if the conditions of the linearity test are met. As explained in the Anova Table, the results of the linearity test show that the value of iDeviation from Linearity is 0.940> 0.05 , indicating that the teacher output variable has a linear relationship with the learning outcome variable.

\section{8) Hypothesis testing $1\left(\mathrm{H}_{1}\right)$}

Hypothesis 1 would be acknowledged if there is an impact of teacher motivation on student learning results at SD Negeri 01 Simpang Agung, Simpang Sub-District, assuming a significance value of 0.05 and tcount $>t$ table. 


\begin{tabular}{|c|c|c|c|c|c|c|}
\hline & & & Table & Hypothesis 1 & & \\
\hline \multirow{2}{*}{\multicolumn{2}{|c|}{ Model }} & \multicolumn{2}{|c|}{ Coefficients } & $\begin{array}{l}\text { Standardized } \\
\text { Coefficients }\end{array}$ & \multirow[t]{2}{*}{$\mathrm{t}$} & \multirow[t]{2}{*}{ Sig. } \\
\hline & & B & $\begin{array}{l}\text { Std. } \\
\text { Error }\end{array}$ & Beta & & \\
\hline \multirow[t]{2}{*}{1} & (Constant) & 570.512 & 6.033 & & 94.566 & 0.001 \\
\hline & Motivation & 0.050 & 0.066 & 0.114 & 2.750 & 0.047 \\
\hline
\end{tabular}

a. Dependent Variable: Learning Outcomes

The significance value is 0.0470 .05 , and the tcount $2.750>\mathrm{t}$ table 1.98282 is understood from the table above, so it can be inferred that $\mathrm{H} 1$ is accepted.
If there is an impact of instructor success on student learning outcomes, Hypothesis 2 would be acknowledged.

9) Hypothesis testing $2\left(\mathrm{H}_{2}\right)$

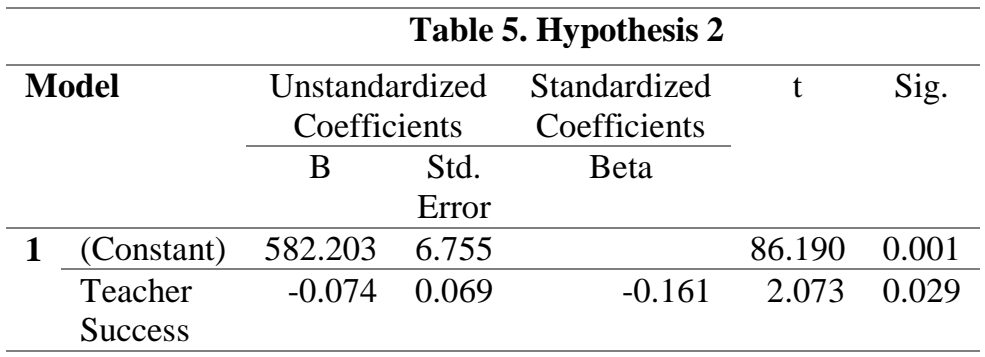

\section{a. Dependent Variable: Learning Outcomes}

It is known from the table above that the significance value is $0.029<0.05$ and tcount $2.073>$ ttable 1.98282 , thus it can be concluded that $\mathrm{H} 2$ is accepted.

10) Hypothesis testing $2\left(\mathrm{H}_{3}\right)$
If there is an impact of teacher motivation and success on student learning outcomes, Hypothesis 3 would be acknowledged. SD Negeri 01 Simpang Agung, Simpang Sub-District, South OKU Regency, as well as the situation if the significance value is 0.05 and F count $>$ Ftable.

Table 6. Hypothesis 3

\begin{tabular}{|c|c|c|c|c|c|}
\hline Model & $\begin{array}{l}\text { Sum of } \\
\text { Squares }\end{array}$ & $\mathrm{df}$ & $\begin{array}{l}\text { Mean } \\
\text { Square }\end{array}$ & $\mathrm{F}$ & Sig. \\
\hline 1 Regression & 58.769 & 2 & 29.379 & 11.161 & $.032^{\mathrm{b}}$ \\
\hline Residual & 1063.241 & 42 & 25.315 & & \\
\hline Total & 1122.000 & 44 & & & \\
\hline
\end{tabular}

a. Dependent Variable: Teacher Performance

b. Predictors: (Constant), School culture, Organizational

Commitment

The table shows that the significance value is Sig.0.032 0.05 and the F count is 11.161>. F table 3.09, it is possible to infer that $\mathrm{H} 3$ is appropriate.

This study is consistent with Hendra's (2018) results, and it is endorsed by offering clear and high motivations for learning, which will have a positive and important effect on the learning outcomes of vocational students. As a result, learning goals can be optimized in the context of student learning outcomes [9].

This study is consistent with previous studies on the impact of qualification and teacher success on improving student learning outcomes at SMP Negeri 2 Banda Aceh, which concluded that there is a positive effect [10]. Other studies also concluded that there are other variables that influence student learning outcomes, namely physiological factors [11].

In line with this study, the effect of principal supervision and teacher work motivation on teacher performance concludes that principal supervision has a positive and significant effect on teacher performance in schools. Teacher work motivation has a positive and significant effect on performance. Simultaneously or together, the two independent variables (principal supervision and teacher work motivation) have an influence on the dependent variable (teacher performance) [12]. 


\section{CONCLUSION}

The following are the findings of this study: (1) there is an effect of motivation on student learning outcomes; and (2) there is an effect of motivation on student learning outcomes. State Elementary School Simpang Agung, Simpang Sub-District, South OKU Regency with a 41.3 percent effect, (2) success has an effect on student learning results at State Elementary School 01 Simpang Agung, Simpang Sub-District, South OKU Regency. (3) There is an impact of teacher motivation and success on student learning outcomes at State Elementary School 01 Simpang Agung, Simpang Sub-District, South OKU Regency with a 26.2 percent effect with a 52 percent impact.

\section{ACKNOWLEDGMENT}

Our deepest gratitude goes to Teachers in SD Negeri 01 Simpang Agung, Chancellor of Palembang PGRI University, Director of the Postgraduate Program of PGRI Palembang University and the Education Management Study Program of PGRI Palembang University, who have supported us in doing this extraordinary thing. This project is funded independently. We also want to thank our Education Management friends who helped us a lot in a short time frame to complete this project.

\section{REFERENCES}

[1] Sobri, M., \& Moerdiyanto, M. (2014). Pengaruh kedisiplinan dan kemandirian belajar terhadap hasil belajar ekonomi Madrasah Aliyah di Kecamatan Praya [The influence of discipline and independent learning on economic learning outcomes in Madrasah Aliyah in Praya District]. Harmoni Sosial: Jurnal Pendidikan IPS, 1(1).

[2]. Kristiawan, M., \& Lian, B. (2019). The Correlation Between Supervision of Headmaster and Interpersonal Communication with Work Ethos of the Teacher. European Journal of Education Studies.

[3]. Lian, B., \& Fitria, H. (2020). Pengaruh Lingkungan Kerja dan Motivasi Kerja terhadap Kinerja Guru SMA di Kecamatan Muara Padang [The Effect of Work Environment and Work Motivation on the Performance of High School Teachers in Muara Padang District]. Jurnal Intelektualita: Keislaman, Sosial dan Sains, 9(1), 167-178.

[4]. Marini, M., As'ari, A. R., \& Chandra, T. D. (2017). Peningkatan motivasi belajar siswa melalui penerapan pendekatan Realistic Mathematics Education (RME) [Increasing student motivation through the application of the Realistic Mathematics Education (RME) approach]. Jurnal
Pendidikan: Teori, Penelitian, dan Pengembangan, 2(4), 470-477.

[5] Istiarini, R., \& Sukanti, S. (2012). Pengaruh Sertifikasi Guru dan Motivasi Kerja Guru Terhadap Kinerja Guru SMA Negeri 1 Sentolo Kabupaten Kulon Progo Tahun 2012 [The Effect of Teacher Certification and Teacher Work Motivation on Teacher Performance in SMA Negeri 1 Sentolo, Kulon Progo Regency in 2012]. Jurnal Pendidikan Akuntansi Indonesia, 10(1).

[6] Sjukur, S. B. (2012). Pengaruh blended learning terhadap motivasi belajar dan hasil belajar siswa di tingkat SMK [The effect of blended learning on learning motivation and student learning outcomes at the SMK level]. Jurnal pendidikan vokasi, 2(3).

[7]. Setiaji, R., Koeswanti, H. D., \& Giarti, S. (2018). Perbedaan Penggunaan Discovery Learning dan Problem Solving terhadap Hasil Belajar IPA Siswa Kelas 4 SD Gugus Cokro Kembang Jenawi Karanganyar [Difference in the Use of Discovery Learning and Problem Solving to the Science Learning Outcomes of Grade 4 Students of SD Gugus Cokro Kembang Jenawi Karanganyar]. Jurnal Basicedu, 2(1).

[8]. Winataputra, U. S., Delfi, R., Pannen, P., \& Mustafa, D. (2014). Hakikat Belajar dan Pembelajaran [The Nature of Learning and Learning]. Jakarta: PAU-PPAI,Univ.Terbuka

[9] Andrizal. (2018). Pengaruh Motivasi Terhadap Hasil Belajar Siswa SMK [The Influence of Motivation on Learning Outcomes of Vocational School Students]. INVOTEK: Jurnal Inovasi Vokasional dan Teknologi, 18(1), 25-30.

[10] Azwar, K., \& Murniati, A. (2015). Pengaruh Sertifikasi dan Kinerja Guru Terhadap Peningkatan Hasil Belajar Siswa di SMP Negeri 2 Banda Aceh [The Effect of Certification and Teacher Performance on the Improvement of Student Learning Outcomes at SMP Negeri 2 Banda Aceh]. Jurnal Administrasi Pendidikan: Program Pascasarjana Unsyiah, 3(2).

[11] Sodik, M., Sahal, Y. F. D., \& Herlina, N. H. (2019). Pengaruh Kinerja Guru Dalam Pelaksanaan Pembelajaran Terhadap Prestasi Belajar Siswa Pada Mata Pelajaran Alquran Hadis [The Effect of Teacher Performance in Learning Implementation on Student Achievement in the Subject of the Qur'an Hadith]. Jurnal Penelitian Pendidikan Islam [SL].

[12] Fitria, H., Aprida, Y., \& Nurkhalis, N. (2020). Pengaruh supervisi kepala sekolah dan motivasi kerja guru terhadap kinerja guru [The effect of principal supervision and teacher work motivation on teacher performance]. Journal of Education Research, 1(2), 160-164. 